University of Nebraska - Lincoln

DigitalCommons@University of Nebraska - Lincoln

\title{
Smooth Brome (Bromus inermis Leyss) and Soil Chemical Response to Concrete Grinding Residue Application
}

\author{
Tom DeSutter \\ North Dakota State University, thomas.desutter@ndsu.edu \\ Patricia Goosen-Alix \\ North Dakota State University, patricia.goosen-alix@ndsu.edu \\ Lyle Prunty \\ North Dakota State University, lyle.prunty@ndsu.edu \\ Paul White Jr. \\ USDA-ARS, paul.white@ars.usda.gov \\ Frank Casey \\ North Dakota State University, francis.casey@ndsu.edu
}

Follow this and additional works at: https://digitalcommons.unl.edu/usdaarsfacpub

DeSutter, Tom; Goosen-Alix, Patricia; Prunty, Lyle; White, Paul Jr.; and Casey, Frank, "Smooth Brome (Bromus inermis Leyss) and Soil Chemical Response to Concrete Grinding Residue Application" (2011). Publications from USDA-ARS / UNL Faculty. 1241.

https://digitalcommons.unl.edu/usdaarsfacpub/1241

This Article is brought to you for free and open access by the U.S. Department of Agriculture: Agricultural Research Service, Lincoln, Nebraska at DigitalCommons@University of Nebraska - Lincoln. It has been accepted for inclusion in Publications from USDA-ARS / UNL Faculty by an authorized administrator of DigitalCommons@University of Nebraska - Lincoln. 


\title{
Smooth Brome (Bromus inermis Leyss) and Soil Chemical Response to Concrete Grinding Residue Application
}

\author{
Tom DeSutter • Patricia Goosen-Alix • \\ Lyle Prunty $\cdot$ Paul White Jr. • Frank Casey
}

Received: 12 December 2010 / Accepted: 14 April 2011 /Published online: 3 May 2011

(C) Springer Science+Business Media B.V. 2011

This article is a U.S. government work, and is not subject to copyright in the United States.

\begin{abstract}
Concrete grinding residue (CGR) is a byproduct created by concrete pavement maintenance operations. The application of CGR to roadside soils is not consistently regulated by state agencies across the USA, which is partially due to the lack of science-based information on its impacts to soils and plants. The objectives of this research were to determine the impact of CGR additions to soil on both smooth brome (Bromus inermis L.) biomass and plant and soil chemical parameters. In a greenhouse study, two soils were treated with two CGR by-products at $8 \%$ and $25 \%$ by weight. Shoot biomass was significantly influenced by the main effects (Soil, CGR, and Rate) and by all twoway interactions, but not consistently positively or negatively correlated. Trace metal concentrations in the shoot biomass were variable, but $68 \%$ of these metals
\end{abstract}

T. DeSutter $(\bowtie) \cdot$ P. Goosen-Alix $\cdot$ L. Prunty $\cdot$ F. Casey Department of Soil Science, North Dakota State University, 214 Walster Hall, P.O. Box 7680, Fargo,

ND 58108-6050, USA

e-mail: thomas.desutter@ndsu.edu

P. Goosen-Alix

e-mail: patricia.goosen-alix@ndsu.edu

L. Prunty

e-mail: lyle.prunty@ndsu.edu

F. Casey

e-mail: francis.casey@ndsu.edu

P. White Jr.

Sugarcane Research Unit, USDA ARS,

5883 USDA Road,

Houma, LA, USA 70360

e-mail: Paul.White@ars.usda.gov had the same concentration or lower in the $25 \%$ CGR treatments compared with the controls. Soil $\mathrm{pH}$ and electrical conductivity were significantly influenced by the main effects and two-way interactions of Soil $\times$ Rate and CGR $\times$ Rate, and soil $\mathrm{pH}$ was significantly greater in the CGR-treated soils. Calcium, $\mathrm{Na}, \mathrm{Mg}, \mathrm{Al}$, and $\mathrm{S}$ concentrations in soils were all influenced by additions of CGR, but trace metal levels in the treatments were all within the range for uncontaminated soils. Ecosystem impact of applying CGR will be dependent upon the quality of CGR and soil characteristics. Controlling the liming potential of CGR should be considered a best management practice.

Keywords Concrete disposal $\cdot$ Industrial by-product . Roadside soil
Abbreviations
10/CA California interstate highway 10 site
94/MN Minnesota interstate highway 94
CGR Concrete grinding residue
DOY Day of year
EC Electrical conductivity

\section{Introduction}

Diamond grinding of highway surfaces improves ride, extends useful highway life, and produces a by-product termed concrete grinding residue (CGR; DeSutter et al. 2011). Regulations addressing CGR differ across states 
within the USA. Oftentimes, CGR is allowed to be distributed onto roadside soils next to the point of grinding (B. Darr, personal communication, 2010, North Dakota Department of Transportation, USA). In contrast, California requires that CGR be contained in storage ponds or class II landfills (T. Pyle, personal communication, 2010, California Department of Transportation, USA). Recently, Nebraska announced plans to require a permit for land application of CGR (Nebraska Department of Environmental Quality 2010; note: the permit was still under review at the time this publication went to press). The costs for disposal of CGR will vary, but ultimately these costs are forwarded to taxpayers.

Even though diamond grinding is routinely done, little research has characterized the environmental impacts of CGR on soils and plants. The two most recent studies are DeSutter et al. (2011) and Shanmugam (2004). Both studies highlight the characterization of solution and solid phases of CGR for inorganic and organic constituents. Concentrations of trace elements were variable across sampling locations in DeSutter et al. (2011) and likely depended on the composition of the concrete and quality of water used for grinding. Addition of fly/bottom ash or slag to concrete mixtures would also increase variability between sites (Bertolini et al. 2004; Ferreira et al. 2003; Mroueh et al. 2001; Papayianni and Anastasiou 2010). No polynuclear aromatic hydrocarbons were found, but application of high rates of CGR to soils increased water infiltration (DeSutter et al. 2011).

Alteration of soil $\mathrm{pH}$ from CGR material addition is likely, which is a concern highlighted by Shanmugam (2004) and the Nebraska Department of Environmental Quality (2010) document. This concern is supported by the elevated $\mathrm{pH}$ of the CGR slurry, which ranged from 11.6 to 12.5 in the DeSutter et al. (2011) study and about 12 in the Shanmugam (2004) study. The liming potential of CGR is evidenced by the range of soil $\mathrm{pH}$ values measured in non-impacted areas (6.3 to 7.5) and comparing these values with areas that received CGR slurry (7.6 to 9.4; Shanmugam 2004).

There is a lack of science-based information about the impacts of CGR on soil chemistry and plant quality, which justifies the need for additional research to evaluate these potential impacts of CGR. The objectives of this research were to determine the impact of adding CGR to soils on (1) smooth brome (Bromus inermis Leyss) growth and elemental con- centrations in its biomass and (2) changes to soil chemical parameters. Smooth bromegrass is a nonnative species that has been commonly seeded in roadside areas across the USA and Canada (D. Kirby, personal communication, 2010); therefore, it was chosen to be an indicator of CGR on plant health.

\section{Materials and Methods}

\subsection{Soil and Concrete Grinding Residue}

The two soils (0 to $15 \mathrm{~cm}$ depths) used for a greenhouse study were a Fargo silty clay (Fine, smectitic, frigid Typic Epiaquerts) and Wyndmere fine sandy loam (course-loamy, mixed, superactive, frigid Aeric Calciaquolls), which were obtained near Fargo, ND, USA $\left(46.86^{\circ} \mathrm{N}, 96.85^{\circ} \mathrm{W}\right)$ and the Albert K. Ekre Grassland Preserve in southeast North Dakota $\left(46.55^{\circ} \mathrm{N}, 97.12^{\circ} \mathrm{W}\right)$, respectively. The Fargo silty clay was collected from a construction site where the soil was used to improve an interstate highway rightof-way, and the Wyndmere fine sandy loam was collected from an undisturbed, natural area with no known history of cultivation or disturbance. Both soils were air-dried, ground to pass through a stainless steel 2-mm sieve, and stored in low-density polyethylene (LDPE) plastic buckets at $25^{\circ} \mathrm{C}$ until the treatments were prepared. The physical and chemical characteristics of both soils were determined using standard soil science methodology by the NDSU Soil Testing Laboratory and are reported in Table 1.

Concrete grinding residues were obtained from Interstate-94 in Minnesota (94/MN) and Interstate-10 in California (10/CA), air-dried, and ground to a fine powder using a mortar and pestle. The chemical characteristics of these two concrete grinding residues, relevant to this study, are reported in Table 2. Particle size distributions are reported in DeSutter et al. (2011). The equivalent calcium carbonate $\left(\% \mathrm{CaCO}_{3}\right)$ and the lime purity $\left(\% \mathrm{CaCO}_{3}\right)$ were determined by Ward Laboratories (Kearney, NE, USA) and were 27.7 and 34.7, respectively, for the $94 / \mathrm{MN}$ and 16.4 and 20.9 , respectively, for the 10/CA. The 94/MN and 10/CA had solution phase $\mathrm{pH}$ values of 11.8 and 12.5, respectively (DeSutter et al. 2011). The solution phase electrical conductivity (EC) of the 94/MN and 10/CA, converted from total dissolved solids (DeSutter et al. 2011) using the assumption that $\mathrm{EC}$ is equivalent to 


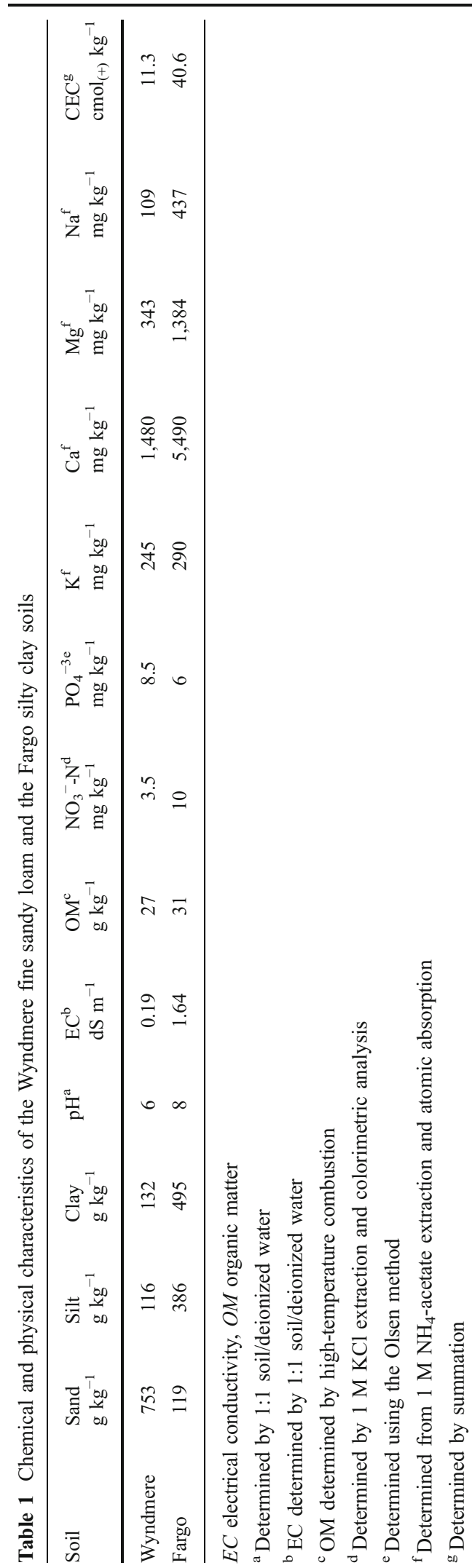

TDS divided by 640 , was 8.5 and $4.8 \mathrm{dS} \mathrm{m}^{-1}$, respectively.

\subsection{Experimental Setup}

In the greenhouse study, each CGR was applied to each soil at rates of $0 \%, 8 \%$, and $25 \%$ by weight, which equated to an broadcast application rate of about 83 and $260 \mathrm{Mg} \mathrm{ha}^{-1}$ for the $8 \%$ and $25 \%$ treatments, respectively, so that the final mass of soil plus CGR in each pot was $1.75 \mathrm{~kg}$. All soil-CGR mixtures were mixed by hand in LDPE plastic bags for $5 \mathrm{~min}$ to improve homogeneity prior to placement into the pots. Smooth brome (20 seeds) was planted into each treatment. Three replications were used for each treatment. All treatments were initiated and terminated on days of year (DOY) 20 and 99 (2010), respectively. After 21 days, the number of plants in each pot was reduced to 12. All pots were watered with tap water to soil field capacity every other day at the start of the experiment and every day starting on DOY 81 . Field capacity was estimated by saturating a sample of each treatment with water, allowing all gravitational water to drain and weighing pots to determine water held. Water soluble plant fertilizer $\left(20-20-20 \mathrm{~N}-\mathrm{P}_{2} \mathrm{O}_{5}-\mathrm{K}_{2} \mathrm{O}\right.$; Jack's Classic; JR Peters Inc., Allentown, PA, USA) was mixed at concentrations of $0.5 \mathrm{~g} \mathrm{~L}^{-1}$ using deionized water (DI), and each pot received $50 \mathrm{~mL}$ of this solution on DOY 71 and 95. The bulk fertilizer product also contained $0.2,0.5,1.0,0.5,0.009$, and $0.5 \mathrm{~g} \mathrm{~kg}^{-1} \mathrm{~B}, \mathrm{Cu}, \mathrm{Fe}, \mathrm{Mn}, \mathrm{Mo}$, and $\mathrm{Zn}$, respectively. In addition, the bulk product had impurity concentrations of $\mathrm{As}, \mathrm{Cd}, \mathrm{Hg}, \mathrm{Pb}$, and $\mathrm{Ni}$ of less than 18, 7.8, 0.04, 47, and $3.7 \mathrm{ng} \mathrm{g}^{-1}$, respectively (Oregon Department of Agriculture 2010).

\subsection{Sample Collection and Analysis}

At DOY 99, plant shoots were clipped at the soil surface, dried at $25^{\circ} \mathrm{C}$ using forced air, and mass determined. A $15-\mathrm{cm}$ deep soil sample was also taken from the center of each pot using a stainless steel probe having a diameter of $1.3 \mathrm{~cm}$. Each soil sample was air-dried at $25^{\circ} \mathrm{C}$, ground to pass through a 2-mm sieve using a mortar and pestle, and stored in LDPE plastic bags. The soil probe and mortar and pestle were thoroughly cleaned between each sample using deionized (DI) water. Plant roots were separated from the soil remaining in the pot using a root washer, dried at 
Table 2 Chemical characterization of the solid phase of concrete grinding residue from two USA roadway grinding locations: Interstate-10 in California (10/CA) and Interstate-94 in Minnesota (94/MN)

All extractions and analyses were done using EPA Method 6010B unless otherwise noted. Used with permission, from Journal of Environmental Quality 40:242-247 (2011)

$B R L$ below report limit (for $\mathrm{Ag}, \mathrm{Hg}, \mathrm{Pt}, \mathrm{Sb}, \mathrm{Se}, \mathrm{Sn}$, and Th the BRLs, at respective units noted in the table, were $1.0,50,0.2,1.0,0.1$, 2.0, and 3.6, respectively), $N R$ not reported by the laboratory

${ }^{a}$ Determined using EPA Method 7470A

${ }^{\mathrm{b}}$ Determined using EPA Method 9038

${ }^{\mathrm{c}}$ Determined using EPA Method 6020A
Chemical parameter

USA roadway identification and location

\begin{tabular}{|c|c|c|}
\hline & \\
\hline & $10 / \mathrm{CA}$ & $94 / \mathrm{MN}$ \\
\hline $\mathrm{Ag}\left(\mathrm{mg} \mathrm{kg}^{-1}\right)$ & BRL & BRL \\
\hline $\mathrm{Al}\left(\mathrm{g} \mathrm{kg}^{-1}\right)$ & 12.0 & 9.3 \\
\hline As $\left(\mathrm{mg} \mathrm{kg}^{-1}\right)$ & 3.7 & 3.7 \\
\hline $\mathrm{Ba}\left(\mathrm{mg} \mathrm{kg}^{-1}\right)$ & 70.2 & 219 \\
\hline $\mathrm{Be}\left(\mathrm{mg} \mathrm{kg}^{-1}\right)$ & 0.4 & 0.6 \\
\hline $\mathrm{Ca}\left(\mathrm{g} \mathrm{kg}^{-1}\right)$ & 50.1 & 63.3 \\
\hline $\mathrm{Cd}\left(\mathrm{mg} \mathrm{kg}^{-1}\right)$ & 0.4 & 0.2 \\
\hline Co $\left(\mathrm{mg} \mathrm{kg}^{-1}\right)$ & 26.7 & 11.9 \\
\hline $\mathrm{Cr}\left(\mathrm{mg} \mathrm{kg}^{-1}\right)$ & 16.3 & 17.1 \\
\hline $\mathrm{Hg}^{\mathrm{a}}\left(\mathrm{ng} \mathrm{g}^{-1}\right)$ & BRL & BRL \\
\hline $\mathrm{Mg}\left(\mathrm{g} \mathrm{kg}^{-1}\right)$ & 5.4 & 16.1 \\
\hline $\mathrm{Na}\left(\mathrm{g} \mathrm{kg}^{-1}\right)$ & 1.5 & NR \\
\hline $\mathrm{Ni}\left(\mathrm{mg} \mathrm{kg}^{-1}\right)$ & 7.7 & 11.1 \\
\hline $\mathrm{Pb}\left(\mathrm{mg} \mathrm{kg}^{-1}\right)$ & 15.7 & 2.2 \\
\hline $\mathrm{Pt}\left(\mathrm{mg} \mathrm{kg}^{-1}\right)$ & BRL & 1.4 \\
\hline $\mathrm{SO}_{4}^{2-\mathrm{b}}\left(\mathrm{mg} \mathrm{kg}^{-1}\right)$ & 1,240 & 4,130 \\
\hline $\mathrm{Sb}\left(\mathrm{mg} \mathrm{kg}^{-1}\right)$ & BRL & BRL \\
\hline $\mathrm{Se}\left(\mathrm{mg} \mathrm{kg}^{-1}\right)$ & BRL & BRL \\
\hline $\mathrm{Sn}^{\mathrm{c}}\left(\mathrm{mg} \mathrm{kg}^{-1}\right)$ & 2.2 & BRL \\
\hline $\mathrm{Sr}^{\mathrm{c}}\left(\mathrm{mg} \mathrm{kg}^{-1}\right)$ & 136 & 371 \\
\hline Th (mg kg $\left.{ }^{-1}\right)$ & BRL & BRL \\
\hline $\mathrm{V}\left(\mathrm{mg} \mathrm{kg}^{-1}\right)$ & 27.1 & 24.1 \\
\hline
\end{tabular}

$60^{\circ} \mathrm{C}$, and weighed. Soil from each core was analyzed for $\mathrm{pH}$ and EC using a 1:1 ratio of soil/DI water and the remaining soil was sent to a private laboratory (Acme Analytical Laboratories Ltd., Vancouver, BC, Canada) for determination of $\mathrm{Ag}, \mathrm{Al}, \mathrm{As}, \mathrm{Ba}, \mathrm{Be}, \mathrm{Ca}, \mathrm{Cd}, \mathrm{Co}, \mathrm{Cr}$, $\mathrm{Hg}, \mathrm{Mg}, \mathrm{Na}, \mathrm{Ni}, \mathrm{Pb}, \mathrm{Pt}, \mathrm{S}, \mathrm{Sb}, \mathrm{Se}, \mathrm{Sn}, \mathrm{Sr}, \mathrm{Th}$, and $\mathrm{V}$ using aqua regia digestion and inductively coupled plasma-mass spectrometry (ICP-MS) using laboratory protocol (vendor code 1F04). Plant biomass was sent to the same laboratory and analyzed for the above elements using nitric acid-aqua regia digestion and ICP-MS (vendor code 1VE2). The elements N, P, K, B, Cu, Fe, $\mathrm{Mn}, \mathrm{Mo}$, and $\mathrm{Zn}$ are not reported for the soil or plant chemistry data due to their significant presence in the fertilizer solution whereas discussions of $\mathrm{As}, \mathrm{Cd}, \mathrm{Hg}$, $\mathrm{Ni}$, and $\mathrm{Pb}$ are included in the analysis discussion.

\subsection{Statistical Analysis}

Data for soils and plants were analyzed using ANOVA (Proc Mixed Ver. 9.1; SAS Institute, Cary,
NC, USA). A three-way ANOVA was conducted with CGR rate, CGR source, and soil type as fixed effects and replication as a random effect. Means of significant tests were separated using paired $t$ tests. Plant growth was also compared with soil chemical and physical parameters using a pairwise comparison technique in JMP (Ver. 8.0; SAS Institute, Cary, NC, USA). All analysis was conducted at levels of $\alpha=$ 0.05 , and significance was accepted at probabilities $(p)$ of $p \leq 0.05$ for all statistical tests.

\section{Results and Discussion}

\subsection{Shoot Biomass}

Shoot biomass was significantly influenced by the two-way interactions between soil type, CGR source, and CGR rate $($ Soil $\times$ CGR, Soil $\times$ Rate, and CGR $\times$ Rate; Tables 3, 4). The highest shoot growth was observed in the Wyndmere soil amended with $8 \%$ 


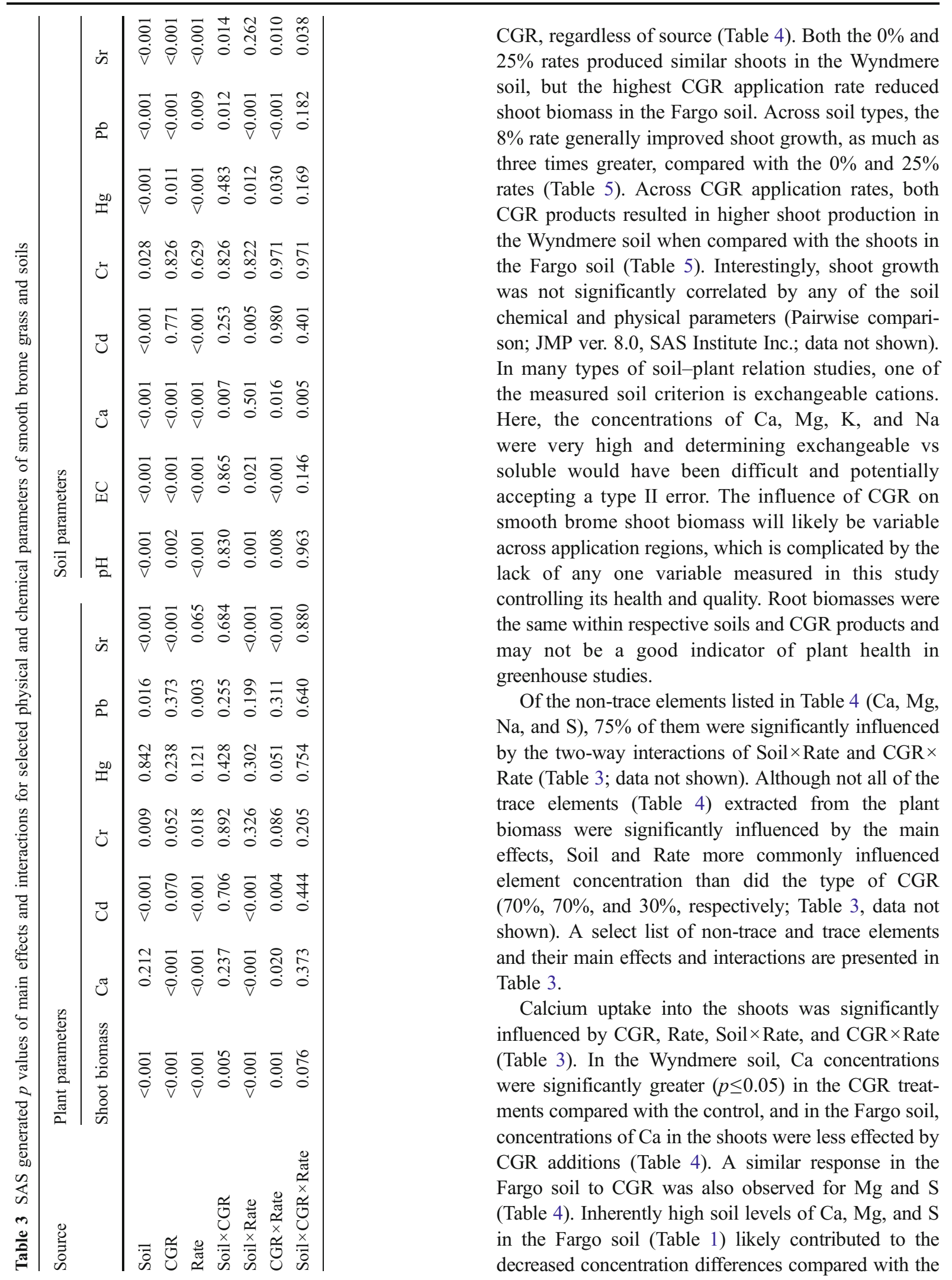


Table 4 Physical and chemical parameters of smooth brome (B. inermis Leyss) biomass grown in two different soils (Wyndmere and Fargo) treated with two different concrete grinding residues $(94 / \mathrm{MN}$ and $10 / \mathrm{CA})$ at three rates of application $(0 \%, 8 \%$, and $25 \%)$

\begin{tabular}{|c|c|c|c|c|c|c|c|c|c|c|c|c|}
\hline \multirow{3}{*}{$\begin{array}{l}\text { Chemical/physical } \\
\text { parameters }\end{array}$} & \multicolumn{6}{|c|}{ Wyndmere fine sandy loam } & \multicolumn{6}{|c|}{ Fargo silty clay } \\
\hline & \multicolumn{3}{|c|}{ 94/MN application rate } & \multicolumn{3}{|c|}{ 10/CA application rate } & \multicolumn{3}{|c|}{ 94/MN application rate } & \multicolumn{3}{|c|}{ 10/CA application rate } \\
\hline & $0 \%$ & $8 \%$ & $25 \%$ & $0 \%$ & $8 \%$ & $25 \%$ & $0 \%$ & $8 \%$ & $25 \%$ & $0 \%$ & $8 \%$ & $25 \%$ \\
\hline Shoot biomass (g) & $2.84 \mathrm{~B}^{\mathrm{a}}$ & $4.51 \mathrm{~A}$ & $2.04 \mathrm{~B}$ & $2.84 \mathrm{~B}$ & $8.23 \mathrm{~A}$ & $3.46 \mathrm{~B}$ & $2.97 \mathrm{~A}$ & $2.66 \mathrm{~A}$ & $1.4 \mathrm{~B}$ & $2.97 \mathrm{~A}$ & $3.65 \mathrm{~A}$ & $1.21 \mathrm{~B}$ \\
\hline Root biomass (g) & $3.83 \mathrm{~A}$ & $6.73 \mathrm{~A}$ & $6.51 \mathrm{~A}$ & $3.83 \mathrm{~A}$ & $3.02 \mathrm{~A}$ & $5.88 \mathrm{~A}$ & $3.65 \mathrm{~A}$ & $3.18 \mathrm{~A}$ & $4.88 \mathrm{~A}$ & $3.64 \mathrm{~A}$ & $7.79 \mathrm{~A}$ & $4.37 \mathrm{~A}$ \\
\hline $\mathrm{Ba}\left(\mathrm{mg} \mathrm{kg}^{-1}\right)$ & $19.3 \mathrm{~A}$ & $17.2 \mathrm{~A}$ & $14.4 \mathrm{~A}$ & $19.3 \mathrm{~A}$ & $19.5 \mathrm{~A}$ & $13.0 \mathrm{~B}$ & $13.3 \mathrm{~A}$ & $12.3 \mathrm{AB}$ & $9.70 \mathrm{~B}$ & $13.3 \mathrm{~A}$ & $10.5 \mathrm{~A}$ & $8.83 \mathrm{~A}$ \\
\hline $\mathrm{Ca}\left(\mathrm{g} \mathrm{kg}^{-1}\right)$ & $3.4 \mathrm{~B}$ & $6.0 \mathrm{~A}$ & $5.9 \mathrm{~A}$ & $3.4 \mathrm{~B}$ & $4.5 \mathrm{~A}$ & $4.7 \mathrm{~A}$ & $4.6 \mathrm{~B}$ & $4.9 \mathrm{AB}$ & $5.8 \mathrm{~A}$ & $4.6 \mathrm{~A}$ & $4.4 \mathrm{~A}$ & $4.8 \mathrm{~A}$ \\
\hline $\mathrm{Cd}\left(\mathrm{mg} \mathrm{kg}^{-1}\right)$ & $0.12 \mathrm{~B}$ & $0.22 \mathrm{~A}$ & $0.24 \mathrm{~A}$ & $0.12 \mathrm{C}$ & $0.26 \mathrm{~A}$ & $0.16 \mathrm{~B}$ & $0.12 \mathrm{~A}$ & $0.12 \mathrm{~A}$ & $0.15 \mathrm{~A}$ & $0.12 \mathrm{~A}$ & $0.12 \mathrm{~A}$ & $0.09 \mathrm{~A}$ \\
\hline Co (mg kg $\left.{ }^{-1}\right)$ & $0.05 \mathrm{~A}$ & $0.06 \mathrm{~A}$ & $0.04 \mathrm{~A}$ & $0.05 \mathrm{~B}$ & $0.17 \mathrm{~A}$ & $0.18 \mathrm{~A}$ & $0.07 \mathrm{~A}$ & $0.11 \mathrm{~A}$ & $0.14 \mathrm{~A}$ & $0.07 \mathrm{~B}$ & $0.11 \mathrm{~B}$ & $0.19 \mathrm{~A}$ \\
\hline $\mathrm{Cr}\left(\mathrm{mg} \mathrm{kg}^{-1}\right)$ & $0.90 \mathrm{~A}$ & $0.90 \mathrm{~A}$ & $0.80 \mathrm{~A}$ & $0.90 \mathrm{~A}$ & $0.93 \mathrm{~A}$ & $1.03 \mathrm{~A}$ & $0.93 \mathrm{~A}$ & $1.03 \mathrm{~A}$ & $1.00 \mathrm{~A}$ & $0.93 \mathrm{~B}$ & $0.97 \mathrm{~B}$ & $1.30 \mathrm{~A}$ \\
\hline $\mathrm{Hg}\left(\operatorname{ng~g~}^{-1}\right)$ & $8.67 \mathrm{~A}$ & $10.3 \mathrm{~A}$ & $10.7 \mathrm{~A}$ & $8.67 \mathrm{~A}$ & $11.3 \mathrm{~A}$ & $9.00 \mathrm{~A}$ & $10.0 \mathrm{~A}$ & $10.3 \mathrm{~A}$ & $11.0 \mathrm{~A}$ & $10.0 \mathrm{~A}$ & $10.7 \mathrm{~A}$ & $7.33 \mathrm{~B}$ \\
\hline $\operatorname{Mg}\left(\mathrm{g} \mathrm{kg}^{-1}\right)$ & $2.7 \mathrm{~A}$ & $2.3 \mathrm{~A}$ & $1.7 \mathrm{~B}$ & $2.7 \mathrm{~A}$ & $2.0 \mathrm{~B}$ & $1.9 \mathrm{~B}$ & $3.6 \mathrm{~A}$ & $2.9 \mathrm{AB}$ & $2.6 \mathrm{~B}$ & $3.6 \mathrm{~A}$ & $3.1 \mathrm{~B}$ & $2.0 \mathrm{C}$ \\
\hline $\mathrm{Na}\left(\mathrm{g} \mathrm{kg}^{-1}\right)$ & $0.02 \mathrm{~B}$ & $0.4 \mathrm{~B}$ & $1.6 \mathrm{~A}$ & $0.02 \mathrm{~A}$ & $0.09 \mathrm{~A}$ & $0.2 \mathrm{~A}$ & $0.1 \mathrm{~B}$ & $0.1 \mathrm{~B}$ & $0.4 \mathrm{~A}$ & $0.1 \mathrm{~A}$ & $0.1 \mathrm{~A}$ & $0.1 \mathrm{~A}$ \\
\hline $\mathrm{Ni}\left(\mathrm{mg} \mathrm{kg}^{-1}\right)$ & $0.43 \mathrm{~B}$ & $0.70 \mathrm{AB}$ & $1.03 \mathrm{~A}$ & $0.43 \mathrm{~B}$ & $0.87 \mathrm{~A}$ & $0.80 \mathrm{~A}$ & $0.73 \mathrm{~B}$ & $0.83 \mathrm{AB}$ & $0.97 \mathrm{~A}$ & $0.73 \mathrm{~A}$ & $1.00 \mathrm{~A}$ & $1.33 \mathrm{~A}$ \\
\hline $\mathrm{Pb}\left(\mathrm{mg} \mathrm{kg}^{-1}\right)$ & $0.97 \mathrm{~A}$ & $0.71 \mathrm{~A}$ & $0.82 \mathrm{~A}$ & $0.97 \mathrm{~A}$ & $0.79 \mathrm{~A}$ & $0.49 \mathrm{~A}$ & $2.10 \mathrm{~A}$ & $1.07 \mathrm{~B}$ & $0.79 \mathrm{~B}$ & $2.10 \mathrm{~A}$ & $1.64 \mathrm{~A}$ & $2.21 \mathrm{~A}$ \\
\hline $\mathrm{S}\left(\mathrm{g} \mathrm{kg}^{-1}\right)$ & $1.3 \mathrm{~B}$ & $1.9 \mathrm{~B}$ & $2.9 \mathrm{~A}$ & $1.3 \mathrm{~B}$ & $2.9 \mathrm{~A}$ & $3.5 \mathrm{~A}$ & $3.0 \mathrm{~A}$ & $2.2 \mathrm{~B}$ & $3.2 \mathrm{~A}$ & $3.0 \mathrm{~B}$ & $2.7 \mathrm{~B}$ & $3.5 \mathrm{~A}$ \\
\hline $\mathrm{Se}\left(\mathrm{mg} \mathrm{kg}^{-1}\right)$ & $0.20 \mathrm{~A}$ & $0.53 \mathrm{~A}$ & $1.73 \mathrm{~A}$ & $0.20 \mathrm{C}$ & $3.13 \mathrm{~B}$ & $7.03 \mathrm{~A}$ & $0.27 \mathrm{~B}$ & $0.47 \mathrm{~A}$ & $0.60 \mathrm{~A}$ & $0.27 \mathrm{C}$ & $4.97 \mathrm{~B}$ & $6.33 \mathrm{~A}$ \\
\hline $\mathrm{Sn}\left(\mathrm{mg} \mathrm{kg}^{-1}\right)$ & $0.03 \mathrm{~A}$ & $0.03 \mathrm{~A}$ & $0.02 \mathrm{~A}$ & $0.03 \mathrm{~B}$ & $0.05 \mathrm{~A}$ & $0.02 \mathrm{~B}$ & $0.05 \mathrm{~A}$ & $0.03 \mathrm{~A}$ & $0.03 \mathrm{~A}$ & $0.05 \mathrm{~A}$ & $0.05 \mathrm{~A}$ & $0.04 \mathrm{~A}$ \\
\hline $\mathrm{Sr}\left(\mathrm{mg} \mathrm{kg}^{-1}\right)$ & $11.0 \mathrm{~B}$ & $18.0 \mathrm{~A}$ & $20.2 \mathrm{~A}$ & $10.6 \mathrm{~A}$ & $11.0 \mathrm{~A}$ & $11.5 \mathrm{~A}$ & $29.0 \mathrm{~A}$ & $24.6 \mathrm{~A}$ & $24.7 \mathrm{~A}$ & $29.0 \mathrm{~A}$ & $19.8 \mathrm{~B}$ & $15.3 \mathrm{~B}$ \\
\hline
\end{tabular}

Concentrations of $\mathrm{Ag}, \mathrm{Al}, \mathrm{As}, \mathrm{Be}, \mathrm{Pt}, \mathrm{Sb}$, Th, and $\mathrm{V}$ were below the quantification limit reported by the laboratory and are not reported ${ }^{a}$ Means followed by different uppercase letters within rows under respective concrete grinding residue source (i.e., $94 / \mathrm{MN}$ application rate or 10/CA application rate) and soil (Wyndmere fine sandy loam or Fargo silty clay) are significantly different at $p \leq 0.05$

Table 5 Dry shoot biomass two-way interactions observed in the greenhouse pot study. (A) Soil $\times$ Rate, (B) CGR source $\times$ Rate, and (C) Soil $\times$ CGR source

\begin{tabular}{lll}
\hline Rate & Soil (g dry biomass) & \\
& Wyndmere & Fargo \\
$0 \%$ & $2.84 \mathrm{~B}^{\mathrm{a}}$ & $2.97 \mathrm{~B}$ \\
$8 \%$ & $6.37 \mathrm{~A}$ & $3.15 \mathrm{~B}$ \\
$25 \%$ & $2.75 \mathrm{~B}$ & $1.31 \mathrm{C}$ \\
Rate & CGR (g dry biomass) & \\
& $94 / \mathrm{MN}$ & $10 / \mathrm{CA}$ \\
$0 \%$ & $2.90 \mathrm{BC}$ & $2.90 \mathrm{BC}$ \\
$8 \%$ & $3.58 \mathrm{~B}$ & $5.94 \mathrm{~A}$ \\
$25 \%$ & $1.72 \mathrm{D}$ & $2.34 \mathrm{CD}$ \\
CGR & Soil (g dry biomass) & \\
& Wyndmere & Fargo \\
$94 / \mathrm{MN}$ & $3.13 \mathrm{~B}$ & $2.34 \mathrm{C}$ \\
$10 / \mathrm{CA}$ & $4.84 \mathrm{~A}$ & $2.61 \mathrm{BC}$ \\
\hline${ }^{\mathrm{a}} \mathrm{Means}$ for each two-way interaction followed by & the same \\
uppercase letter within each group are not significantly different \\
at $p \leq 0.05$
\end{tabular}

Wyndmere soil. Decreased $\mathrm{Mg}$ shoot uptake in the $25 \%$ CGR treatments may have been due to $\mathrm{Ca}$ being preferentially translocated into the plants. A study regarding $\mathrm{Mg}$ uptake in CGR amended soils would need to be conducted to determine if reduced $\mathrm{Mg}$ in the shoots negatively impacts plant health at the levels reported here.

Soil type and CGR rate significantly altered shoot $\mathrm{Cr}$, $\mathrm{Pb}$, and Sr levels (Table 3). When grown in Fargo soil, the shoot $\mathrm{Cr}, \mathrm{Pb}$, and $\mathrm{Sr}$ concentrations were elevated compared with shoots grown in the Wyndmere soil, and additions of CGR did not consistently impact shoot quality compared with the control ( $0 \%$; Table 4$)$. Concrete grinding residue rate also affected $\mathrm{Cr}$ and $\mathrm{Pb}$ levels observed in shoots (Tables 3 and 4). The maximum levels of $\mathrm{Cr}$ and $\mathrm{Pb}$ in shoot biomass reported here (Table 4; 1.30 and $2.21 \mathrm{mg} \mathrm{kg}^{-1}$, respectively) are lower than concentrations reported in plant uptake studies conducted by Xu and Jaffe (2006) (2.71 $\mathrm{mg} \mathrm{kg}^{-1}$; Typha latifolia), Pierzynski and Schwab (1993) (2.6 mg kg-1; Glycine max), respectively, but 
greater here for $\mathrm{Sr}\left(29.0 \mathrm{mg} \mathrm{kg}^{-1}\right)$ than the Collins and Burch (1970) study (5.1 mg kg-1; Brassica alba). Uptake of $\mathrm{Sr}$ has been shown to be positively correlated with $\mathrm{Ca}$ concentrations in the soil (Veresoglou et al. 1995). Given the wide range of plant species found in roadside soils (Forman and Alexander 1998; Tikka et al. 2001), impacts of trace elements from CGR will likely be highly variable.

Of the 40 individual shoot-trace element comparisons in Table 4, 68\% of the trace metals had the same concentration or lower in the high rate $(25 \%)$ compared with the control treatments $(0 \%)$. Trace metal concentrations in the shoots were variable, and only $\mathrm{Ni}$ showed enhanced uptake in both the 94/MN and 10/ CA-Fargo soil treatments. These results may not be reproducible in the field due to the presence of other trace elements in roadside soils (Ho and Tai 1988; Gratani et al. 1992; Garcia and Millan 1998; Shanmugam 2004), which would greatly complicate identifying the source of these elements within shoot biomass. Furthermore, when CGR is added to the soil, changes in soil $\mathrm{pH}$, ionic strength, presence and concentration of anions and cations, plant species present in roadside soils, presence/type of oxides in the soil, presence/concentration of organic matter in the soil, competition for root uptake, and competition for exchange sites with other cations will all influence accumulation of trace metals in plant biomass (Collander 1941; Menzel 1954; Naidu et al. 1994; Roca and Vallejo 1995; Singh and Myhr 1998; Norvell et al. 2000; Basta et al. 2005; Abe et al. 2008).

\subsection{Soil Chemistry}

Soil $\mathrm{pH}$ and EC were significantly influenced by the two-way interactions, Soil $\times$ Rate and $\mathrm{CGR} \times$ Rate (Table 3$)$. Soil $\mathrm{pH}$ was significantly greater $(p \leq 0.05)$ for both soils when CGR was applied, regardless of rate (Table 6). The CGR liming effects were similar to the results of Shanmugam (2004), where they report that at one test site CGR-treated and untreated areas had soil $\mathrm{pH}$ values ranging from about 7.0 to about 8.5 , respectively. Increases in soil $\mathrm{pH}$ may negatively impact availability of some micronutrients to roadside soils (McKenzie 2003). Application of 25\% by weight CGR significantly increased EC of both soils compared with the control and the low, $8 \%$ rate (Table 6). The $94 / \mathrm{MN}$-treated soils exhibited a greater increase in EC compared with the soils treated with
10/CA at respective application rates (Table 6), which was not unexpected due to the $94 / \mathrm{MN}$ having nearly double the solution phase EC compared with the 10/ CA (DeSutter et al. 2011).

All of the non-trace elements, described here as $\mathrm{Ca}$, $\mathrm{Mg}, \mathrm{Na}, \mathrm{S}$, and $\mathrm{Al}$, were significantly influenced by the main effects Soil and CGR, and the two-way interaction $\mathrm{CGR} \times$ Rate, which indicates that the soil type and source of CGR are very important for controlling the concentration of these elements in the soil. Calcium and $\mathrm{Na}$ concentrations in the CGRtreated soils were significantly greater $(p \leq 0.05)$ in the $25 \%$ treatments compared with the $8 \%$ and controls (Table 6). Calcium is the major cation used in Portland cement production and is added as tricalcium silicate, dicalcium silicate, tricalcium aluminate, and tetracalcium aluminoferrite (US Department of Transportation 2010), and calcium sulfate (Bye 1983) and is an essential plant nutrient that is applied through CGR application. The concentration of sodium oxide in Portland cement can vary from 1 to $10 \mathrm{~g} \mathrm{~kg}^{-1}$ (Bye 1983). Although exchangeable $\mathrm{Na}$ was not determined here, addition of any appreciable amount of $\mathrm{Na}$ to soils could lead to dispersion if the soil solution EC is low, based upon electric double-layer theory (Essington 2004). However, given the increase in total $\mathrm{Ca}$ and $\mathrm{EC}$ to the soil through the addition of CGR, the potential for soil dispersion seems remote.

Aluminum was significantly greater $(p \leq 0.05)$ in the Wyndmere soil with the high CGR rate $(25 \%)$ treatments compared with the low CGR rate $(8 \%)$ and controls $(0 \%)$, but not significantly different across treatments in the Fargo soil (Table 6). Magnesium concentrations varied across soils and CGR products and were significantly greater $(p \leq 0.05)$ in the $25 \%$ compared with the $8 \%$ and control soils for the Wyndmere soil (Table 6). Sulfur was typically greater $(p \leq 0.05)$ in the $25 \%$ treatments compared with the $8 \%$ and controls (Table 6), which may have been due to calcium sulfate being added during the cement production process as noted above. Increases in exchangeable $\mathrm{Al}$ or elemental $\mathrm{S}$ may lead to lower soil $\mathrm{pH}$ values, but this would likely be nullified by the liming effect of the CGR.

Considering all 16 trace elements from Table 6, $100 \%, 50 \%$, and $75 \%$ of them were significantly influenced by Soil, CGR, and Rate, respectively, which indicated that these main effects are all important when considering environmental impacts 


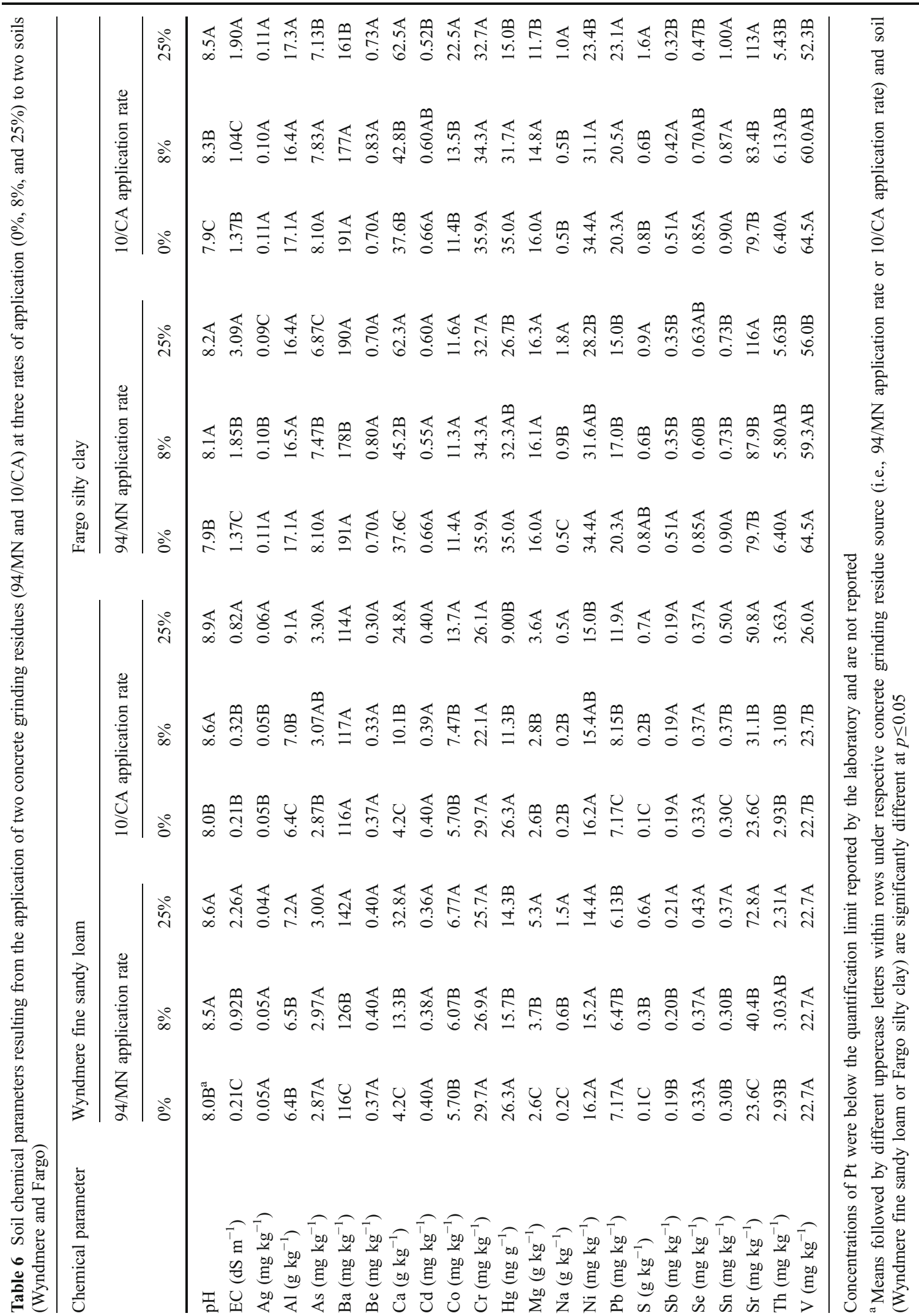


of CGR to soils. The two-way interactions did not influence trace element concentration as consistently as the main effects, but Soil $\times$ Rate and CGR $\times$ Rate did significantly influence $75 \%$ and $47 \%$ of these element concentrations, respectively (Table 3 ). Only $31 \%$ of the trace elements were significantly influenced by the three-way interaction. A select list of non-trace and trace elements and their main effects and interactions are presented in Table 3.

Addition of CGR to soil resulted in many of the trace elements being diluted or having the same concentrations as the control treatments. For example, Cd was not significantly different $(p>0.05)$ within respective Wyndmere treatments and was significantly diluted $(p \leq 0.05)$ for the 10/CA-treated Fargo soil (Table 6). Other trace elements that showed similar results as $\mathrm{Cd}$ were $\mathrm{Be}, \mathrm{Cr}, \mathrm{Hg}, \mathrm{Ni}$, and $\mathrm{Se}$. The only trace element that was significantly greater $(p \leq 0.05)$ in the high CGR rate $(25 \%)$, when compared with the control treatments $(0 \%)$, was $\mathrm{Sr}$, which had a maximum concentration of $116 \mathrm{mg} \mathrm{kg}^{-1}$ in the 94/MN-Fargo soil treatment. Many of the other trace elements were variably diluted or concentrated within the treatments and $\mathrm{Pt}$ was below the quantification limit reported by the laboratory. Concentrations of the trace metals reported here were all within the range reported for non-contaminated soils (McBride 1994; Essington 2004).

Addition of $25 \%$ CGR significantly decreased ( $p \leq$ 0.05) $\mathrm{Hg}$ concentrations in both soils compared with the levels in the controls (Table 6). The two CGR sources used in this study had $\mathrm{Hg}$ concentrations below $50 \mathrm{ng} \mathrm{g}^{-1}$, which was then further diluted by preparing the CGR treatments. Mercury concentrations in CGR may not always be as low as those used in this study (DeSutter et al. 2011). The $\mathrm{Hg}$ results reported here are similar to those reported in DeSutter et al. (2010) for roadside soils in North Dakota.

\section{Conclusion}

The objective of this research was to determine how CGR additions to soil impact growth of smooth brome and soil properties. Concrete grinding residues will vary in their physical and chemical nature, and their impact on the environment will depend on the concrete composition, quality of grinding water, and the presence of organics on road surfaces. Several conclusions can be drawn from the research conducted here, including (1) soil $\mathrm{pH}$ and EC will likely increase after CGR application due to the liming potential and total dissolved salts present in CGR, respectively; (2) smooth brome growth will be a function of soil type, CGR, and rate of application of this by-product, and thus, CGR additions to soil will variably impact this plant species; (3) uptake of $\mathrm{Ca}$, an essential plant nutrient, by smooth brome will likely be accentuated by the application of CGR; (4) trace metal uptake by smooth brome is variable and will depend on CGR and many soil chemical properties; (5) soil application rates of CGR will likely not increase trace metal levels in either soils or smooth brome above those found in uncontaminated soils; and (6) application of CGR at the $8 \%$ rate (83 $\mathrm{Mg} \mathrm{ha}^{-1} ; 37 \mathrm{tac}^{-1}$ ) was generally beneficial for smooth brome growth, but application rates greater than $8 \%$ should be well justified and are not recommended since the rate at which smooth brome responded negatively was not determined here.

Even though this by-product has been widely produced across the USA since the 1960s, very little research has been conducted on its impacts on the environment. As a waste by-product, CGR bears little resemblance to biosolids, coal combustion waste ash, or foundry sands. Thus, regulation of CGR application to soils will need to be based on results such as those presented here and the other papers referenced within. Although the total dissolved solids concentration would be difficult for grinding companies to control, limiting the liming potential of CGR should be strongly considered as a best management practice.

Acknowledgments Technical assistance was provided by Kevin Horsager. Funding for sample analyses was provided for by the International Grooving and Grinding Association.

\section{References}

Abe, T., Fukami, M., \& Ogasawara, M. (2008). Cadmium accumulation in the shoots and roots of 93 weed species. Soil Science and Plant Nutrition, 54, 566-573.

Basta, N. T., Ryan, J. A., \& Chaney, R. L. (2005). Trace element chemistry in residual-treated soil: Key concepts and metal bioavailability. Journal of Environmental Quality, 34, 49-63.

Bertolini, L., Carsana, M., Cassago, D., Curzio, A., \& Collepardi, M. (2004). MSWI ashes as mineral additions 
in concrete. Cement and Concrete Research, 34, 18991906.

Bye, G. C. (1983). Portland cement: composition, production, and properties (1st ed., pp. 1-13). New York: Pergamon.

Collander, R. (1941). Selective absorption of cations by higher plants. Plant Physiology, 16, 691-720.

Collins, H. A., \& Burch, H. E. (1970). Accumulation of strontium and other cations by plant species grown on the two soil types. Crop Science, 10, 312-314.

DeSutter, T., Viall, E., Rijal, I., Murdoff, M., Guy, A., Pang, X., et al. (2010). Integrating field-based research into the classroom: An environmental sampling exercise. Journal of Natural Resources \& Life Sciences Education, 39, 132-136.

DeSutter, T., Prunty, L., \& Bell, J. (2011). Concrete grinding residue characterization and influence on infiltration. Journal of Environmental Quality, 40, 1-6.

Essington, M. E. (2004). Soil and water chemistry: An integrative approach (1st ed., pp. 1-34). Boca Raton: CRC. 311-397.

Ferreira, C., Ribeiro, A., \& Ottosen, L. (2003). Possible applications for municipal solid waste fly ash. Journal of Hazardous Materials, B96, 201-216.

Forman, R. T. T., \& Alexander, L. E. (1998). Roads and their major ecological effects. Annual Review of Ecology, Evolution, \& Systematics, 29, 207-231.

Garcia, R., \& Millan, E. (1998). Assessment of Cd, Pb and Zn contamination in roadside soils and grasses from Gipuzkoa (Spain). Chemosphere, 37, 1615-1625.

Gratani, L., Taglioni, S., \& Crescente, M. F. (1992). The accumulation of lead in agricultural soil and vegetation along a highway. Chemosphere, 24, 941-949.

Ho, Y. B., \& Tai, K. M. (1988). Elevated levels of lead and other metals in roadside soil and grass and their use to monitor metal depositions in Hong Kong. Environmental Pollution, 49, 37-51.

McBride, M. B. (1994). Environmental chemistry of soils (1st ed., pp. 308-341). New York: Oxford University Press.

McKenzie, R. (2003). Soil pH and plant nutrients. AGRI-FACTS, Practical information for Alberta's agriculture industry. http:// www1.agric.gov.ab.ca/\$department/deptdocs.nsf/all/ agdex6607/\$file/soilph.pdf?OpenElement. Accessed 22 November 2010

Menzel, R. G. (1954). Competitive uptake by plants of potassium, rubidium, cesium, and calcium, strontium, barium from soils. Soil Science, 77, 419-425.

Mroueh, U., Eskola, P., \& Laine-Ylijoki, J. (2001). Life-cycle impacts of the use of industrial by-products in road and earth construction. Waste Management, 21, 271-277.

Naidu, R., Bolan, N. S., Kookana, R. S., \& Tiller, K. G. (1994). Ionic-strength and $\mathrm{pH}$ effects on the sorption of cadmium and the surface charge of soils. European Journal of Soil Science, 45, 419-429.

Nebraska Department of Environmental Quality. (2010). General NPDES Permit Number NEG500000, a general NDPES permit authorizing land application of concrete/grinding slurry. Lincoln: Wastewater Section.

Norvell, W. A., Wu, J., Hopkins, D. G., \& Welch, R. M. (2000). Association of cadmium in Durum wheat grain with soil chloride and chelate-extractable soil cadmium. Soil Science Society of America Journal, 64, 2162-2168.

Oregon Department of Agriculture. (2010). Registered fertilizer products: 20-20-20 all purpose with micronutrients water soluble plant food. http://oda.state.or.us/dbs/heavy_metal/ detail.lasso?-op=eq\&product_id=1133. Accessed 22 November 2010

Papayianni, I., \& Anastasiou, E. (2010). Production of highstrength concrete using high volume of industrial byproducts. Construction and Building Materials, 24, 14121417.

Pierzynski, G. M., \& Schwab, A. P. (1993). Bioavailability of zinc, cadmium, and lead in a metal-contaminated alluvial soil. Journal of Environmental Quality, 22, 247254.

Roca, M. C., \& Vallejo, V. R. (1995). Effect of soil potassium and calcium on caesium and strontium uptake by plant roots. Journal of Environmental Radioactivity, 28, 141159.

Shanmugam, H. (2004). Assessment and mitigation of potential environmental impacts of Portland cement concrete highway grindings. From Washington State University (USA): http://www.dissertations.wsu.edu/ Thesis/Fall2004/h_shanmugam_121304.pdf. Accessed 22 November 2010

Singh, B. R., \& Myhr, K. (1998). Cadmium uptake by barley as affected by $\mathrm{Cd}$ sources and $\mathrm{pH}$ levels. Geoderma, 84, 185-194.

Tikka, P. M., Hogmander, H., \& Koski, P. S. (2001). Road and railway verges serve as dispersal corridors for grassland plants. Landscape Ecology, 16, 659-666.

US Department of Transportation. (2010). Portland cement. http:// www.fhwa.dot.gov/infrastructure/materialsgrp/cement.html. Accessed 22 November 2010

Veresoglou, D. S., Tsialtas, J. T., Barbayiannis, N., \& Zalidis, G. C. (1995). Caesium and strontium uptake by two pasture plant species grown in organic and inorganic soils. Agriculture, Ecosystems \& Environment, 56, 37-42.

$\mathrm{Xu}, \mathrm{S}$., \& Jaffe, P. R. (2006). Effects of plants on the removal of hexavalent chromium in wetland sediments. Journal of Environmental Quality, 35, 334-341. 